\title{
DISTRIBUTION AND AVAILABILITY OF HUMAN RESOURCE: A GEOGRAPHIC ANALYSIS OF JHUNJHUNU DISTRICT, RAJASTHAN
}

\author{
Imran Khan \\ Assistant Professor (Geography) RP Dular Girls College, Bissau, (Rajasthan), India \\ Email: drimrankc@gmail.com
}

\begin{abstract}
The spatial distribution of populations can be described at different geographic scales. The Growing population expands over a larger area as individuals move from highdensity patches to the fringe of the population. Under favourable conditions, isolated demes expand and coalesce with the main population, spreading an outbreak over large areas. Spatial distribution of population can be affected in several ways. Result climate changes can be noted on geographic distribution of suitable habitats. However, the most serious anthropogenic effects on spatial patterns are habitat fragmentation, alteration and pollution of aquatic ecosystems, and redistribution (intentionally or unintentionally) of various species. Humans also are responsible for the introduction of a large and growing number of plant and animal species to new regions as a result of transportation of commercial species and agricultural products. Early models represented population expansion as a simple diffusion process. Modelling of spatial distribution has been facilitated by recent development of geographic information systems (GIS) and geostatistical techniques. This paper deals with the spatial distribution, urban and rural population and characteristics of population distribution, density and growth in Jhunjhunu District. The purpose of the study is to highlight the trends of population growth, identify the densely populated areas, analyse the distribution of population as well as predict the future expected population of Jhunjhunu District. As the conclusion of the study it was observed that population of the District had steadily increased by the passage of time. By analysing population it seems that the present population size will be twofold in the near future.
\end{abstract}

Key words: Human Resources, Distribution and Availability, Geographical analysis

\section{Introduction}

Resources are a natural and human asset that we use to fulfil our needs. Therefore, the elements available on the earth that can be used by humans to meet their own needs are called resources. Different scholars have defined the resources as follows. According to James Fischer, "Resources are such things that are used in fulfilling human needs and desires. Similarly, according to Zimmermann, "in reality, the meaning of resources is to achieve any objectives. This objective fulfils personal needs and social goals. According to Johnston, "a concept which specifies the human satisfaction, prosperity and resources that give power, Labour, enterprising skills, exchange, stable capital structure, technical knowledge, social stability and cultural and physical characteristics can be considered as resources of any country. The population is also an important resource for any region because the use of natural resources depends on the quality and efficiency of human resources. Human resources mean are taken from the size of the population of the country and its active involvement in production, along with its quality, intelligence, awareness. Where available natural resources of the country are merely means of economic development the same human resources have the potential of economic activities. They are both the beginning and the end of the economic activities of the community.

\section{Population Distribution}

The total area of Jhunjhunu district is $5928 \mathrm{sq}$. Km. Total population of the district as per 2001 census was $19,13,689$ which increased to $2,137,045$ in 2011. If we look at the data of 2001 we found that the population density in Jhunjhunu was 323 kilometres which increased to 361 in 2011. According to 2001 census sex ratio were 946 at Jhunjhunu which increased to 950 by 2011 census on per 1000 male compared to 2001. The modest increase of 4 women has been observed in the sex ratio in the district. The total number of males in the district was $9,83,526$, 
while the number of females was $9,30,163$, compared to males. In this sequence, after taking a look at the figures of district of 2011, it is found that in 2011 the total Population of the district was $2,137,045$ of which the total number of men was 1,095,896 and the total number of women was $1,041,149$. According to the 2011 figures, the total urban population in Jhunjhunu district is $1,647,966$. Apart from this, the rural population was $4,890,79$. The total numbers of the habitant villages in Jhunjhunu district is 910 . In which about 80 percent of the district's population lives. In 1901 the total population was 3,41,572. The population of the district, however, increased to $19,136,89$ in 2001. And in 2011, the population of Jhunjhunu district increased by 11.67 percent and became $2,137,045$. Through the following table we can analyse very well the population of Jhunjhunu.

Figure 01: Key Map of study Area

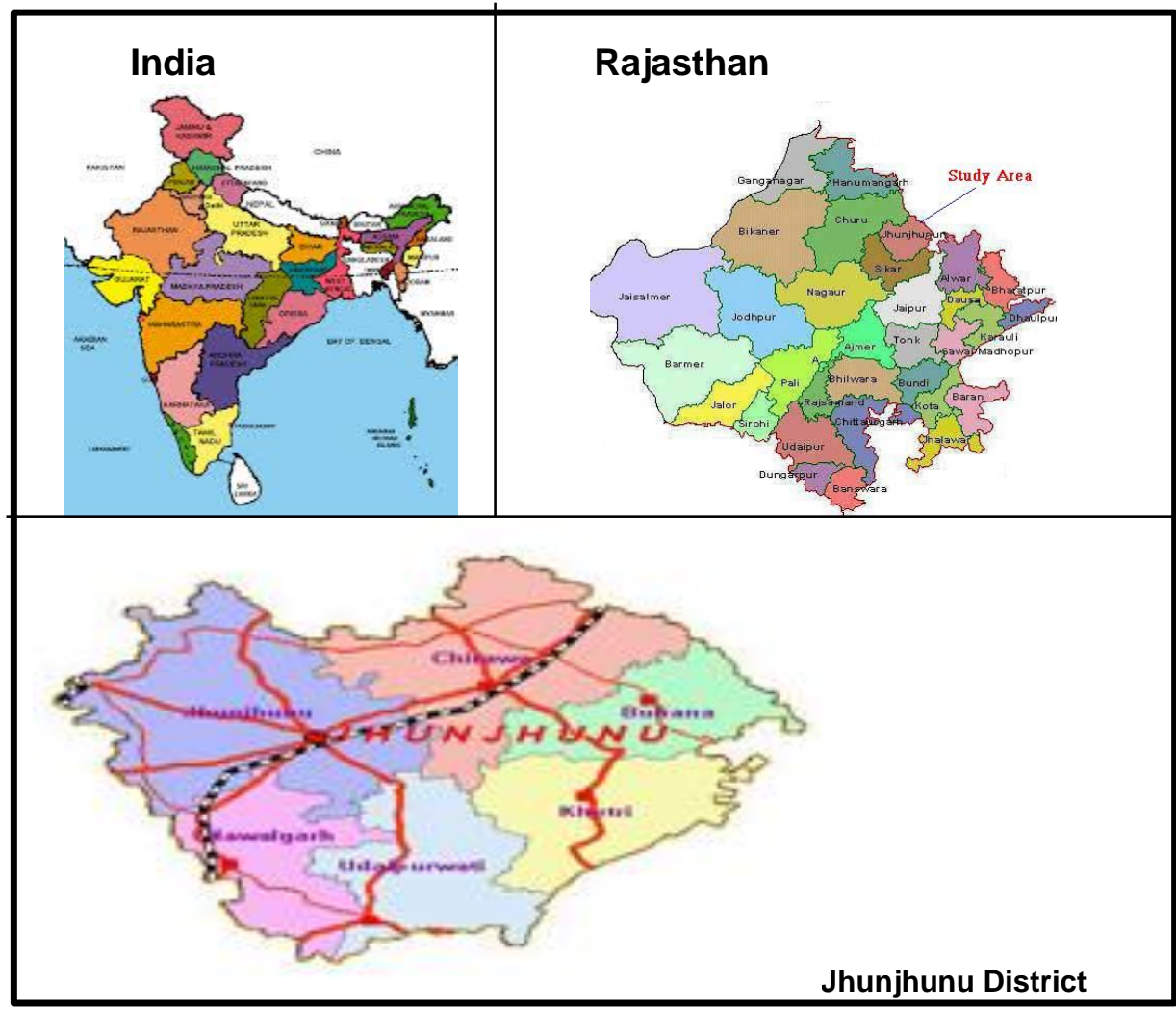

Table 01: Decimal Growth in Jhunjhunu District (1901-2011)

\begin{tabular}{|c|c|c|c|c|}
\hline Year & Male & Female & Total & Decimal Growth (\%) \\
\hline 1901 & $1,81,338$ & $1,60,234$ & $3,41,572$ & - \\
\hline 1911 & $1,93,692$ & $1,75,689$ & $3,69,081$ & +08.05 \\
\hline 1921 & $1,88,072$ & $1,65,068$ & $3,73,140$ & -04.32 \\
\hline 1931 & $2,15,880$ & $1,89,639$ & $4,05,519$ & +14.83 \\
\hline 1941 & $2,60,986$ & $2,30,017$ & $4,91,003$ & +21.08 \\
\hline 1951 & $3,00,988$ & $2,87,748$ & $5,88,736$ & +19.90 \\
\hline 1961 & $3,70,457$ & $3,49,193$ & $7,19,650$ & +22.24 \\
\hline 1971 & $4,81,873$ & $4,47,357$ & $9,29,230$ & +29.12 \\
\hline 1981 & $6,19,313$ & $5,92,270$ & $12,11,583$ & +30.69 \\
\hline 1991 & $8,19,448$ & $7,62,973$ & $15,82,421$ & +30.61 \\
\hline 2001 & $9,83,526$ & $9,30,163$ & $19,13,689$ & +20.93 \\
\hline 2011 & $1,09,5896$ & $1,041,149$ & $2,137,045$ & +11.67 \\
\hline
\end{tabular}

Source: District census handbook, 2014 Jhunjhunu

After studying the above table, we found that during the period from 1901 to 2011 , the fastest rate of population in the district was in 1981. Which was 30.61 percent And in 1991 the population growth rate was 30.61 Whereas the population of the district this year was $15,82,421$. The minimum increase in these 110 years was recorded in the year 1921 that was 0.432 percent. When the population of the district was 3,69,081 in 1911 the same changed from 4.32 to $3,73,140$ in 1921 . In fact, the analysis of the table reveals that there have been a lot of ups and downs in the population of the district after the regular year intervals. Similarly in 2001 the total population of the district was 1913,689 which increased from 11.67 percent in 
2011 to $2,137,045$. Compared to 1991 , the population of Jhunjhunu district increased by 36.90 percent in 2011.

Table 02: Distribution of Population of Jhunjhunu District and Rajasthan (1931-2011)

\begin{tabular}{|c|c|c|}
\hline Year & Jhunjhunu District & Rajasthan \\
\hline 1931 & $4,55,199$ & $1,17,47,974$ \\
\hline 1941 & $4,91,003$ & $1,38,63,659$ \\
\hline 1951 & $5,88,736$ & $1,59,70,774$ \\
\hline 1961 & $7,19,650$ & $2,01,55,602$ \\
\hline 1971 & $9,29,230$ & $2,57,65,806$ \\
\hline 1981 & $12,11,583$ & $34,361,860$ \\
\hline 2001 & $15,82,421$ & $44,005,990$ \\
\hline 2011 & $19,13,689$ & $5,64,73,122$ \\
\hline
\end{tabular}

Source: District census handbook, 2014

After the study of the table, it is found that in the initial years in the district there is a slow increase of population but between 1931 and 1961, the population increased in the district by gradual and rapid growth. So during this time the population increased from 405519 to 719650 and in 1921, the population was 9,29,230, in 1981 it was 12,11,583, in 1991 it was $15,82,421$ and in 2001 it was 19,13,689 and in 2011, the population of the district increased 11.67 percent and became 2,137,045.

\section{Tehsil wise Population Distribution}

In Jhunjhunu district there are total six tehsils i.e Jhunjhunu, Chidawa, Buhana, Khetri, Nawalgarh and Udaipurwati. Population distribution in these tehsils is uneven. According to the 2011 census, Jhunjhunu tehsil has the highest population of Jhunjhunu district which is 538174. The tehsil with the lowest population of the district is Buhana, where the total population is only 223405 . We can understand the population distribution in the district's tehsils by the following table. After the study of the table, it is found that the total population of Jhunjhunu tehsil is 538174 which are 25.18 percent of the total population of the district.

Table 03: Tehsil wise population in Jhunjhunu, 2011

\begin{tabular}{|c|l|c|c|c|}
\hline \multirow{2}{*}{$\#$} & \multirow{2}{*}{ Tehsil } & \multicolumn{3}{|c|}{ Total Population } \\
\cline { 3 - 5 } & & Male & Female & Total \\
\hline 1. & Jhunjhunu & 271670 & 266504 & 538174 \\
\hline 2. & Chirawa & 245099 & 230988 & 476087 \\
\hline 3. & Buhana & 116131 & 107274 & 223405 \\
\hline 4. & Khetri & 145208 & 132738 & 277946 \\
\hline 5. & Nawalgarh & 166750 & 159913 & 326663 \\
\hline 6. & Udaipurwati & 151038 & 143732 & 294770 \\
\hline Total & & 1095896 & 1041149 & $2,137,045$ \\
\hline
\end{tabular}

Source: District Statistical Handbook 2014

Apart from this 476087 population resides in Chirawa out of which 245099 are males and 230988 are females. The table shows that the least population in the district resides in Buhana tehsil. The total population of this tehsil is 223405 which are 10.45 percent of the total population of the district. In which 116131 male and 107274 are female. In this sequence if we look at the distribution of population in other tehsils of the district then we found that Nawalgarh is the tehsil with maximum population in the district after Chirawa tehsil. According to the 2011 census a total of 326663 populations reside in the Nawalgarh tehsil in which 166750 were male and 159913 were female. In this sequence the tehsils with the fourth maximum population are Udaipurwati. According to the 2011 census, the total population of this tehsil is 294770 out of which the number of males and females are 151038 and 143732 respectively.

\section{Current Scenario of Population}

The state of Rajasthan has touched various highs in the economic, social and other important areas in the last several years but the growing population here overshadowed its many achievements. Since the state has limited reserves of natural resources due to this the problem 
becomes more difficult. If we analyse the increasing population in the context of Jhunjhunu district it is found that there has been a rapid increase in the population of the city in the last 50 to 60 years. Nearly 60 years ago in 1941 the population of the city was about 4.9 lakhs and it increased to about 7.19 lakhs by 1961 . It took 20 years for more than 2 lakh population to increase. The city got the next 2.0 lakh population in just 10 years. The population growth rate at this time was 19.12 percent in the decade from 1971 to 1981 . There was an unexpected increase of 2 lakh in the city's population. The population growth rate at this time was 30.39 per cent. After this from 1981 to 1991 the total population increased to 3.782421 with an increase of 3.7 lakhs. The growth rate from 1981 to 1991 was 30.61 percent which was the highest growth rate till 2001. Between 1991 to 2001 the population of the city increased by 3.3 lakhs and the total population of the city reached 1913689. In the next 10 years, i.e. in 2011, the population crossed the 21 lakh mark in 2011 the total population of the district reached to 2137045 in 2011.

\section{Occupational Structure}

The total number of tenants in the district is 521692 . From which 252595 male and 269097 females are involved in this work. In Jhunjhunu district the percentage of male counterparts is 46.66 and the percentage of female counterparts is 76.18 , which is much more than the percentage of males. In Jhunjhunu district a total of 507672 people in the rural area are engaged in tenants' work, of which 245121 are males and 262551 are females. A total of 67.44 per cent of the people are engaged in this work in rural areas of the district, of which 57.63 per cent are male and 80.19 are female. In this sequence, if we look at the number of tenants in the urban areas of the district, it is found that in the urban areas of the district a total of 14020 persons are engaged in this work, of which 7474 males are 6546 females. According to the percentage, a total of 9.88 percent of the population in urban areas of the district are engaged in this work of which 6.44 percent and 25.32 percent respectively of men and women. After tenants the second main occupation in Jhunjhunu district is farming. According to the 2011 figures, the total number of agricultural laborers in the district is 68878 . Thus a total of 7.70 percent of the people are working in agriculture work. From which there are 41286 males and 27592 females. In the district 7.63 percent men and 7.81 percent women are engaged in farming. Looking at the number of people engaged in this work in rural and urban areas of the district, we find that the total number of agricultural laborers working in rural areas is 64571 out of which 38100 are males and 26471 are females. Number of persons engaged in agricultural work in urban areas of the district 4307 which is 3.04 percent of the total population. In the district, 3186 men and 1121 women are working in agriculture work in urban areas.

\section{Working Population}

The total number of working people in Jhunjhunu district is 894649 , which is 41.86 percent of the total number of the district. If we look at the number of women and men in the working population in the district, 541392 men and 353257 women are working in the district. If the number of people working in the district is analysed in the context of rural and urban areas, than we found that out of the total working population in the district, 752752 people are working in rural areas, which is 45.68 per cent of the district. A total of 425348 males and 327404 females are employed in the villages of the district.

Table 04: Distribution of Working, Marginal and non-working Population in the District

\begin{tabular}{|l|l|l|l|l|l|l|l|l|l|}
\hline Cat. & \multicolumn{3}{|c|}{ Working } & \multicolumn{3}{c|}{ Marginal } & \multicolumn{3}{c|}{ Non-working } \\
\hline & Male & Female & Total & Male & Female & Total & Male & Female & Total \\
\hline Rural & 425348 & 327404 & 752752 & 87912 & 195908 & 283820 & 417370 & 477844 & 895214 \\
\hline Urban & 116044 & 25853 & 141897 & 9369 & 8647 & 18016 & 137134 & 210048 & 347182 \\
\hline Total & 541392 & 353257 & 894649 & 97281 & 204555 & 301836 & 554504 & 687892 & 1242396 \\
\hline
\end{tabular}

Source: District Statistical Handbook 2011

\section{Non-Working Population}

Under this class, such persons are included who do not do any kind of production work themselves. Therefore, in this category, the elderly, handicapped, students, unemployed, wives, and pensioners are included. The total number of such population in Jhunjhunu district in 2011 is 1242396 in which 554504 are males and 687892 are females in the district. The total number of non-working people in the rural areas of the district is 895214 in which 417370 are 
males and 477844 are females. Similarly, the total number of non-working women in cities of the district is 137134 and the number of non-working women in cities is 210048 .

\section{Marginal Population}

Under this, a class of people who have not done any work at any time in a year before the calculation is done. Workers who do not do any kind of work most of the time are kept under this category. According to the figures of 2011, out of the total population in Jhunjhunu district, 301836 persons fall under the marginal population. In which there are 97281 males and 204555 females. The district has a total marginal population of 33.74 per cent, of which 17.97 percent of the men and 57.91 percent of the females fall under the marginal population.

\section{Occupational Organization of Population}

The commercial organization of the population of a particular area is based on the different types of work done by the population of that region. Almost all types of businesses are found in Jhunjhunu district, Such as tenants, agricultural labourers, persons engaged in family industry etc. Through the following table, we can understand the ratio of population in various occupations of rural and urban population of Jhunjhunu district.

Table 05: Occupation wise Population Distribution (Percent) 2011

\begin{tabular}{|l|l|l|l|l|l|l|l|l|}
\hline Cat. & \multicolumn{2}{|c|}{ Tenants } & \multicolumn{2}{c|}{ Agriculture } & \multicolumn{2}{c|}{ Traditional Industries } & \multicolumn{2}{c|}{ Others } \\
\hline & Male & Female & Male & Female & Male & Female & Male & Female \\
\hline Rural & $57-63$ & $80-19$ & $08-96$ & $08-09$ & $01-37$ & $0-65$ & $32-05$ & $11-07$ \\
\hline Urban & $6-44$ & $25-32$ & $02-75$ & $04-34$ & $03-11$ & $07-40$ & $87-70$ & $62-95$ \\
\hline Total & $46-66$ & $76-18$ & $07-63$ & $07-81$ & $01-74$ & $01-14$ & $43-98$ & $14-87$ \\
\hline
\end{tabular}

Source: District Statistical Handbook 2011

\section{Conclusion}

The study reveals that population growth in Jhunjhunu district experienced over the last few years had some severe negative effects. The most obvious and common impact is that overpopulation has put a great strain on the natural resources of the district. As we know, some of the resources available to us come in limited quantities, for example, fossil fuels. When the population explosion happened, these resources are becoming rarer and will one day run out completely. The increased population had also leaded to increased pollution and industrialization. This has adversely affected our district's natural environment leading to more health problems in the majority of the population. And the growing population results, the lake of food and other resources causing famines and various such disasters. And as we are currently noticing in India, overpopulation also leads to massive unemployment. Overall the economic and financial condition of densely populated regions deteriorates due to the population explosion.

\section{References}

1. Allan M. Findlay, Peters, Gray L., Larkin, Robert P. (2014) Population Geographyproblems, Concepts and problems-Published by Kendall /Hunt Publishing Company 2460 Karper Baul Vard, Dobque.

2. Chora K., Gulati S.C. (2001) Migration, Common Property Resources and Environmental degradation-inter-linkege in India's Arid and Semi-Arid Regions, Published by Sage Publications new Delhi.

3. Choudhary A.B. (2007) Forests, Environment and Man, Dya Publishing house- Delhi.

4. Chouhan A. S. (2007) Society and Environment - Jain brothers, New Delhi.

5. District Statistical handbook, Jhunjhunu District, 2011.

6. Divan S. Rosen cranz A. (2002) Environment law and Policy in India ( $2^{\text {nd }}$ edition) Cases, materials and status- oxford university press.

7. Edward F. Bergman, William H. Renwik, T. Vasantha Kumaran (2008) Introduction to Geography- people, places and Environment - Darling Kindersley (India) (p) Ltd.

8. Eleventh five year plan- $2007-2012$, (vol. I) Inclusive growth.

9. Goutam A. (2007) Environment Geography - Sharda Pustak Bhawan, Allahabad.

10. Guha R. (2006) Social Eclogy, Oxford University Press.

11. Khan I. (2016) A geographical analysis of Increasing population and environmental problems- A case study of Jhunjhunu District. (Ph.D Thesis) 